\title{
The European transition to a green energy production model: Italian feed-in tariffs scheme \& Trentino Alto Adige mini wind farms case study
}

\author{
La transición europea a un modelo de producción de energía verde: \\ Esquema italiano de tarifas y estudio de caso de mini parques eólicos de \\ Trentino Alto
}

Javier Heredia Yzquierdo ${ }^{\mathrm{a}} \sim(1)$, Antonio Sánchez-Bayón ${ }^{\mathrm{b},{ }^{*}} \nabla(1)$

a) EAE Business School (Spain)

b) Universidad Rey Juan Carlos: Móstoles, Madrid (Spain)

* Primary Contact: antonio.sbayon@urjc.es (Antonio Sánchez-Bayón)

\begin{abstract}
The Europe 2020 Strategy is aimed at making the EU into a smart, sustainable and inclusive economy by 2020 . This Strategy has to promote environmental policies and economic opportunities. Back in 2007 Italy was performing slightly below average and way below the most advanced EU Member States as far as percentage of green energy of the total energy produced in Italy. Measures were taken and though the Italian regulation around green energies has been hectic though effective. Italian legislation recently passed will put emphasis on the relevance of a Green Power strategy by guarantying an attractive minimum price per Kw produced through clean and environmental friendly sources, notably from Wind energy sources. Within the sector a new area is grafting attention: the mini wind farms. The Trentino Alto Adige region in Northern Italy has taken particularly profit of the national legal framework and has develop a further regional frame that has placed the region on top of the Italian green energy production charts. The local idiosyncrasy is making of the mini wind farms a case study
\end{abstract}

Keywords: energy transition; green energy; Europe 2020; wind energy; mini wind farms

JEL Classification: F53; G14; K23; O32

\section{Resumen}

La Estrategia Europa 2020 tiene como objetivo convertir a la UE en una economía inteligente, sostenible e integradora para 2020. Esta estrategia ha de generar políticas medioambientales y oportunidades económicas. Hacia 2007, Italia se comportaba ligeramente por debajo del promedio y muy por debajo de los Estados miembros más avanzados de la UE en la producción de energía verde como porcentaje de la energía total producida en Italia. Se tomaron medidas y, aunque la regulación italiana en torno a las energías verdes ha sido voluble, sí ha resultado efectiva. La legislación italiana recientemente aprobada pone énfasis en la relevancia de una estrategia de energía verde al garantizar un precio mínimo atractivo por Kw producido a través de fuentes limpias y amigables con el medio ambiente, especialmente de fuentes de energía eólica. Dentro del sector, una nueva área que está atrayendo atención son los mini parques eólicos. La región de Trentino Alto Adige en el norte de Italia se ha beneficiado particularmente del marco regulatorio nacional y ha desarrollado un nuevo marco local, que ha colocado a la región en la cima de las listas italianas de producción de energía verde. La idiosincrasia local está haciendo de los mini parques eólicos un caso de estudio
\end{abstract}

Palabras clave: transición energética; energía verde; Europa 2020; energía eólica; mini parques eólicos Clasificación JEL: F53; G14; K23; O32 


\section{Introduction}

This paper has its foundations on Comparative Law and Politics System (Sánchez-Bayón, 2014, 2015), applied to European Union Law, and how it deals with the issue of current Italian legislation passed about green power strategy by guarantying an attractive minimum price per Kw produced through clean and environmental friendly sources. These Laws mean an opportunity for the implementation of green energy production sources in Italian soil.

The Italian strategy is yet a fine example of the European targets set by the European Commission in their strategy for a transition to a low CO2 emissions economy. The ambitious strategy is defined by the Europe 2020 strategy for smart sustainable and inclusive growth. As the former President of the European Commission-EC Mr. Barroso stated:

The Commission is proposing five measurable EU targets for 2020 that will steer the process and be translated into national targets: for employment; for research and innovation; for climate change and energy; for education; and for combating poverty. They represent the direction we should take and will mean we can measure our success. (European Commission, 2010)

Thus once the goals of the EC are to reach a significant reduction of Greenhouse gas emissions and to arrive to a significant increase of energy from renewables and to achieve to better energy efficiency. These goals are quantified by the very EC as "greenhouse gas emissions $20 \%$ (or even $30 \%$, if the conditions are right) lower than 1990. $20 \%$ of energy from renewables. 20\% increase in energy efficiency" (European Commission, 2015) $)^{1}$.

Table 1. Overview of Europe 2020 (countries emissions reductions)

\begin{tabular}{|l|c|c|}
\hline \multicolumn{1}{|c|}{ Member States targets } & $\begin{array}{c}\text { Emissions reduction targets } \\
\text { (compared to 2005 levels) }\end{array}$ & $\begin{array}{c}\text { Renewable energy } \\
\text { (in \% of gross final energy consumption) }\end{array}$ \\
\hline GERMANY & $\begin{array}{c}\mathbf{- 2 0 \%} \\
\text { (compared to 1990 levels) }\end{array}$ & $\mathbf{2 0 \%}$ \\
\hline FRANCE & $-14 \%$ & $18 \%$ \\
\hline ITALY & $-14 \%$ & $23 \%$ \\
\hline UK & $\mathbf{- 1 3 \%}$ & $\mathbf{1 7 \%}$ \\
\hline
\end{tabular}

Source: European Commission (2015)

Back in 2007 Italy was performing slightly below average and way below the most advanced EU Member States as far as percentage of green energy of the total energy produced in Italy with the peculiarity that most of its renewable energy sources came from Geothermal origin though one could argue that the Italian geographical position would allow the country an above European average number of hours of sun.

Figure 1. Share of renewables in gross inland energy consumption, 2007

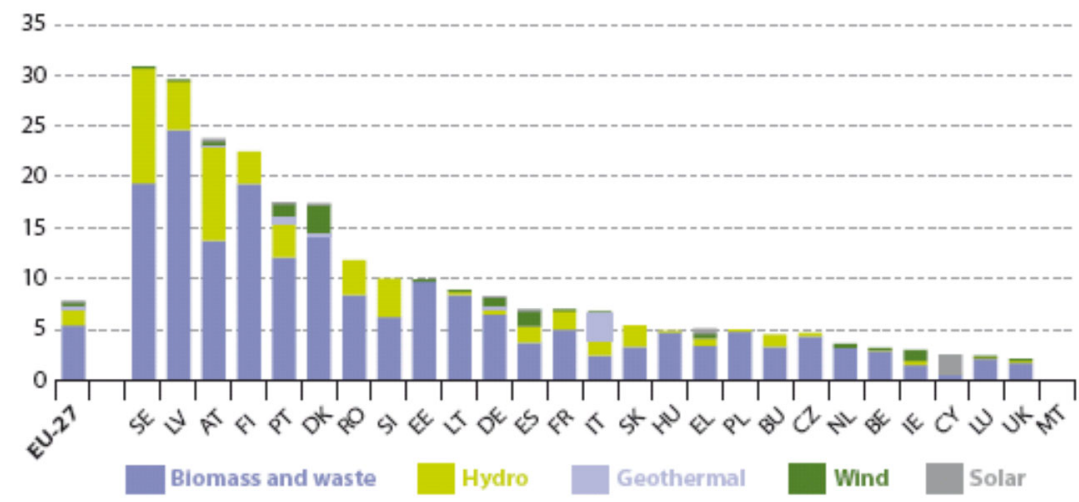

Source: Eurostat (2018)

At the time being the Protocol of Kyoto had already entered into force on $16^{\text {th }}$ February 2005 (UNFCCC, 2014 ) and the European Union had been mounting pressure since. The European Commission felt this date "sends a strong signal that there is increasing political will to move towards a global 'climate-friendly' economy" (European Commission, 2005). Italy was a signatory of the Kyoto Protocol and Italy ratified the Kyoto Protocol on $31^{\text {st }}$ May 2002 as an Annex 1 Party (United Nations, 2005). The pressure had legislative results in Italy as the Government felt it had to raise the amount of green energy produced in the Country. One of the measure implemented meant the increase of photovoltaic energy via incentives. The Italian Government had implemented a feed-in scheme since July 2005 (VV.AA., 2013). The feed-in scheme is the program which grants incentives for electricity generated by photovoltaic (PV) plants connected to the grid: 
Feed-in tariffs (FIT) are a policy mechanism designed to accelerate investment in renewable energy technologies. Producers of renewable energy are paid a set rate for the electricity they produce, usually differentiated according to the technology used (wind, solar, biomass, et.al.) and the size of the installation. FITs guarantee that anyone who generates electricity from a renewable energy source-whether they are a homeowner, small business, or large electric utility-is able to sell that electricity into the grid and receive long-term payments for each kilowatt-hour produced (Ayre, 2013).

This system was strengthen by the Italian Government in 2007 with the second incentives law or second feedin scheme which granted very high incentives to photovoltaic plants. At the same time the prices of photovoltaic plants was also going down as the US Department of Energy explains: "As a rough measure of this trend, the capacity- weighted average installed price declined from $\$ 6.21 / \mathrm{W}$ for projects installed during 2004-2008 to \$3.94/W for projects installed during 2009-2010, and to \$3.42/W for projects installed in 2011" (Feldman et al., 2014). This provided with additional incentives for the private sector and the research community to drive innovation and develop competitive and clean photovoltaic-PV technologies for the future and to a certain boom in that segment, with many plants built in Italy succeeded in having more green energy produced, with a spike in the PV installed in MW in the period 2008-2011. In the year 2011 only almost 4,000 new MW from PV sources were installed. This meant more than double the installations of 2010. Philip G. Jordan described the situation as "meteoric" "Italy's solar sector has seen "meteoric" growth in the past decade, bolstered by a strong renewable energy portfolio standard and aggressive subsidies. It is estimated that Italy installed as much PV as the United States in 2012" (Jordan, 2013).

Figure 2. Italian PV Market 2006-2011

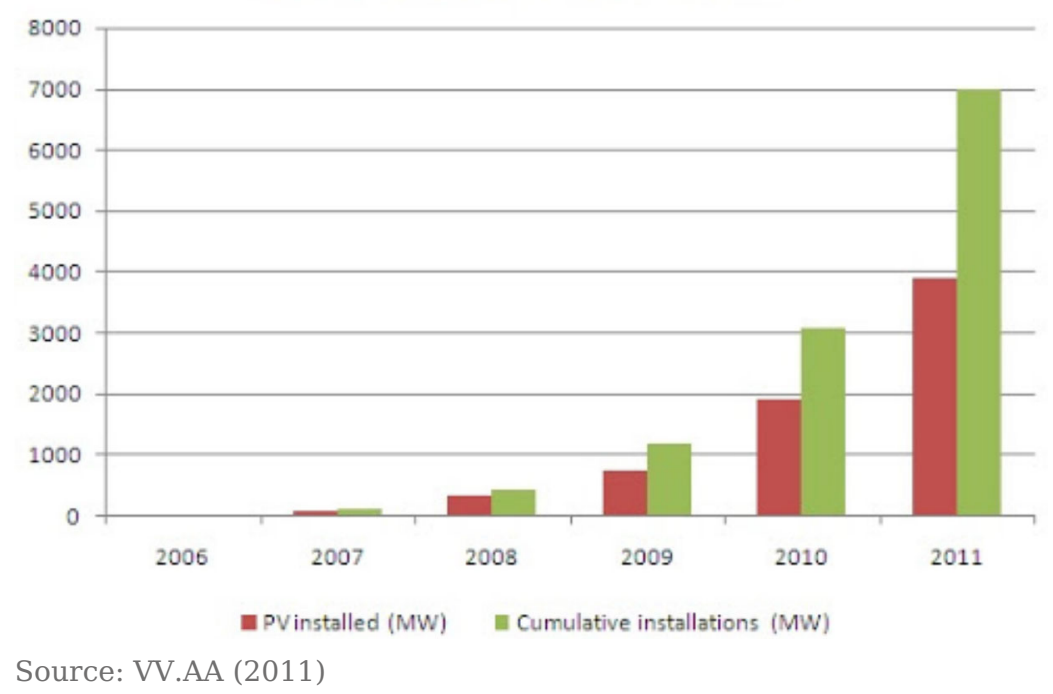

This boom was halted by the Italian Government in 2012. The Italian Government had been reducing the incentives and in 2012 it cut the incentives for photovoltaic plants completely. The third feed-in scheme lowered the incentives in 2010 and the forth feed- in scheme of 2011 was still lower, and finally the fifth feedin scheme cut almost completely the incentives to green energy. June 2012 was a turning point for the Italian situation. However, a new turning point has just been implanted in June 2016 that is changing again the Italian green energies scenario.

\section{Regulation balance}

\subsection{European scenario - Europe 2020}

In 2011, the European Commission's Communication "Roadmap to a low carbon economy in 2050" established that greenhouse gas (GHG) emissions should be cut down by at least $80 \%$ by 2050 from their 1990 levels, to ensure competitiveness and economic growth in the energy transition, and to meet the Kyoto Protocol pledges. In 2016, the Commission presented its "Clean Energy Package", consisting of legislative proposals to develop Renewable energies-RES and the electricity market, to improve energy efficiency, and to define the governance of the Energy Union, with the following targets by 2030: 27\%.

In a world where global electricity consumption will increase in areas with rapidly expanding residential solar and/or electric vehicles (EVs), and where major thermal generators are closed there will be challenges for electricity network operators, regulators, and governments (VV.AA., 2017). The Europe 2020 Strategy is aimed at making the EU into a smart, sustainable and inclusive economy by 2020. This Strategy will create environmental policies and economic opportunities. The European Environment Agency numbers some of the opportunities as: 
Feed-in tariffs (FIT) are a policy mechanism designed to accelerate investment in renewable energy technologies. Producers of renewable energy are paid a set rate for the electricity they produce, usually differentiated according to the technology used (wind, solar, biomass, et.al.) and the size of the installation. FITs guarantee that anyone who generates electricity from a renewable energy source-whether they are a homeowner, small business, or large electric utility-is able to sell that electricity into the grid and receive long-term payments for each kilowatt-hour produced (Ayre, 2013).

The Europe 2020-a strategy for smart, sustainable and inclusive growth was revealed by the EC in 2010 through a Communication ${ }^{2}$. The EC proposed three main priorities: A smart growth by developing an economy based on knowledge and innovation. A sustainable growth by promoting a more resource efficient, greener and more competitive economy and an inclusive growth by fostering a high-employment economy delivering social and territorial cohesion. This is being promoted by a set of binding legislation: The 2020 package is a set of binding legislation to ensure the EU meets its climate and energy targets for the year 2020. The package sets three key targets: 20\% cut in greenhouse gas emissions (from 1990 levels) 20\% of EU energy from renewables $20 \%$ improvement in energy efficiency. The targets were set by EU leaders in 2007 and enacted in legislation in 2009. They are also headline targets of the Europe 2020 strategy for smart, sustainable and inclusive growth.

For the purposes of this Paper one would like to highlight that one of the goals underlined by the EC in their Communication was that the "20/20/20" climate/energy targets should be met (European Commission, 2009). In 2008 the European Commission proposed binding legislation to implement the 20-20-20 targets. This "climate and energy package" became law in 2009. European policy makers introduced goals for the year 2020 in a number of different sectors. In the energy sector the 2020 goals were based on the three pillars leading European energy policy: Security of supply, competitive markets and sustainability. The 2020 energy goals are to have a 20\% (or even 30\%) reduction in CO2 emissions compared to 1990 levels, a $20 \%$ increase in energy efficiency and $20 \%$ of the energy coming from renewable sources. This last "20" target is having a particular impact on the green energy sources policies coming from different Member States.

There has been controversy about the $20 \%$ figure as it seems it is based on marketing reasons better than on scientific ones. Furthermore the European Parliament had already proposed a more demanding target of $25 \%$. However it was reasoned by the EC that its target is grounded "in studies carried out to determine what level would be feasible given the EU's generating resources, what level would be affordable for the EU as a whole and what level would appear suitably ambitious" (VV.AA., 2008).

Moreover regarding the most relevant impact on the efficiency of the European Renewable energy policies can be attributed to the wind energy. Serrano and Lacal- Arántegui cited the work developed in 2011, by Klessmann et al. that evaluated the status of renewable energy deployment in the EU by means of the effectiveness indicators. The results showed that during the period 2003-2009 the highest average policy effectiveness was reached for onshore wind (4.2\%), followed by biofuels (3.6\%) biomass electricity (2.7\%), biogas (1.6\%) and photovoltaic (1.5\%) (Klessmann, Held, Rathmann, \& Ragwitz, 2011).

Other number support this idea: The European Union installed $16.8 \mathrm{GW}$ (15.6 GW in the EU) of gross additional wind power capacity in 2017, marking a record year on annual installations. With a total net installed capacity of $168.7 \mathrm{GW}$, wind energy remains the second largest form of power generation capacity in Europe, closely approaching gas installations (Fraile \& Mbistrova, 2018).

Figure 3. Total power generation capacity in the European Union 2005-2017

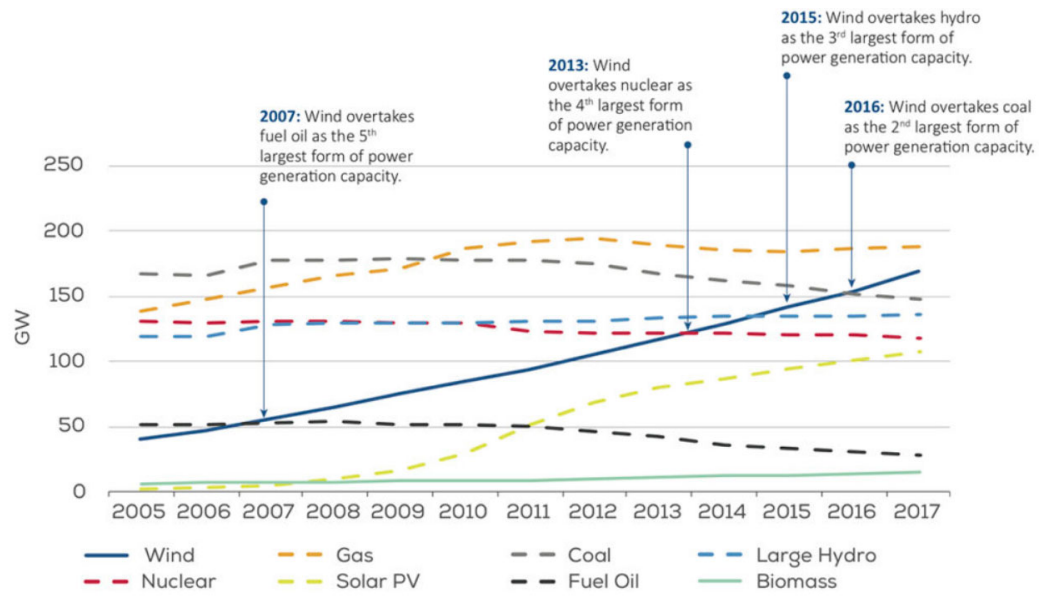




\subsection{Italian case - Trentino Alto Adige region legal situation}

Eurostat shows as the peculiarity of the Italian case. Following its historic record, Italy has already achieved its 2020 target of energy share coming from renewable sources.

Figure 4. EU Share of energy from renewable sources 2004-2016

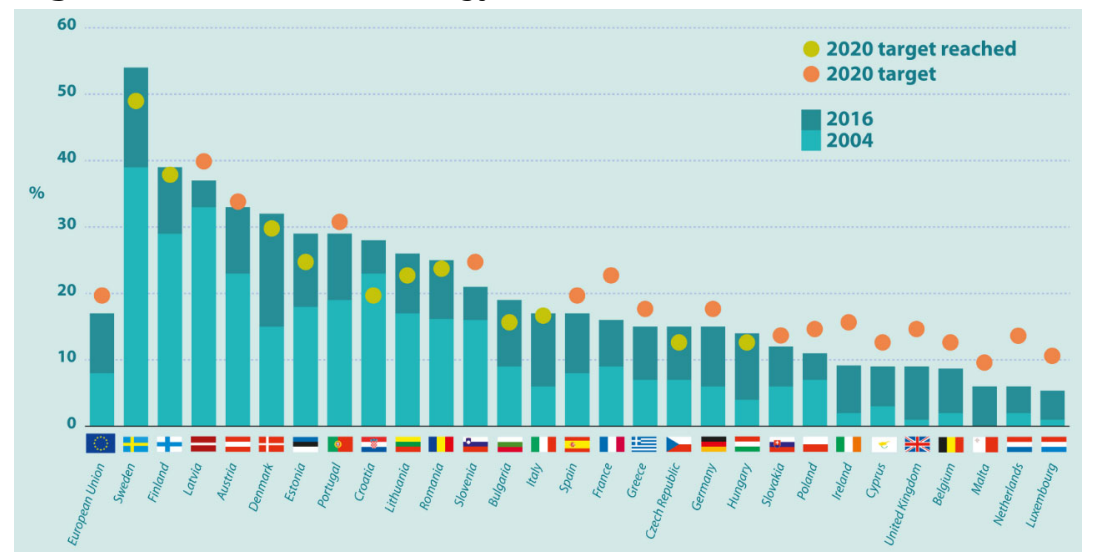

Source: Eurostat (2018)

Furthermore, in November 2017 the Italian Ministry for the Economic Development, Ministry for the Environment and Keeping of the Sea and the Land (Ministero dello Sviluppo Economico e del Ministero dell'Ambiente e della Tutela del Territorio e del Mare) released the National Program on National Energy (Strategia Energetica Nazionale-SEN) ${ }^{3}$.

The National Program or SEN establishes a set of goals to 2030. It emphasized the goal of decarbonising electricity generation in Italy. In order to achieve such a goal the SEN launches in a first phase, aiming to the cessation of the use of coal and then to be extended to the others fossil fuels, with undoubted environmental and health benefits and with a contribution to the European objectives, additional to the increase in renewable energies and to the improvement of energy efficiency (VV.AA., 2017).

The SEN stablishes that Italy contributes to coal generation in Europe with a percentage of $5 \%$, lower than other countries. The national production coming from coal sources accounts for $15 \%$ of the total. This percentage is further reduced due to some closures recently intervened and destined to further decreases in the coming years linked to constraints environmental or market conditions. Moreover, for autonomous corporate policies consistent with sustainability strategies, major companies have already planned and announced the cessation of its coal production on a horizon of definite time.

Furthermore there are other objectives of the SEN regarding Security Goals for 2030 that involve the penetration of renewable sources Energy (VV.AA., 2017):

1. Provide the system with innovative tools and infrastructures to ensure adequacy and the maintenance of safety standards, intervening with instruments of market to guide the behavior of operators (capacity market).

2. Increasing the meshing of the network and the degree of interconnection in Europe and in the Mediterranean.

3. Ensuring flexibility of the electricity system in a context of increasing penetration of renewable sources that will have to reach a share of $55 \%$, of progressive electrification of demand and growth of widespread self-production.

4. Promoting technological development to ensure further elements of flexibility.

5. Promoting the resilience of the system towards extreme weather events and emergencies, taking into account the intensification of coordination at European level in the activities of prevention of risks of a cross-border nature.

6. Intensifying the processes of evaluating investments from a cost-benefit effectiveness point of view, in order to identify, from time to time, the solutions that allow to achieve the aforementioned objectives at the lowest cost for the consumer.

7. Simplifying the authorization and execution times of the interventions and update the regulation on the operation of thermoelectric plants (VV.AA., 2017).

Moreover and regarding energy efficiency the data shows a reduction of final consumption from 118 to 108 Mtep with a saving of about 10 Mtep to 2030 renewable sources: $28 \%$ of renewables on total consumption in 2030 compared to $17.5 \%$ in 2015 (VV.AA., 2018). 
In sectorial terms, the objective is divided into a share of renewables on consumption electricity of $55 \%$ to 2030 compared to $33.5 \%$ of 2015 ; in a share of renewables on thermal uses of $30 \%$ to 2030 compared to $19.2 \%$ in 2015; in a share of renewables in transport of $21 \%$ to 2030 compared to $6.4 \%$ in 2015 reduction of the energy price differential: limit the cost gap between Italian gas and that of northern Europe (in 2016 equal to about $2 € / \mathrm{MWh}$ ) and that on prices electricity compared to the EU average (around $€ 35$ / MWh in 2015 for the average family and $25 \%$ on average for businesses) cessation of the production of electricity from coal with an acceleration target of 2025, to be achieved through a precise plan of infrastructural interventions rationalization of the oil downstream, evolving towards bio refineries and an increasing use of sustainable biofuels and LNG in heavy and maritime transport in place of oil derivatives towards decarbonisation to 2050 (VV.AA., 2017): compared to 1990, a decrease in emissions of 39\% to 2030 and of $63 \%$ to 2050 double investments in clean energy research and technological development: from 222 million in 2013 to 444 million in 2021 promotion of sustainable mobility and shared mobility services new investments in networks for greater flexibility, adequacy and resilience; greater integration with Europe; diversification of sources and routes of gas supply and more efficient management of flows and demand points reduction of energy dependence from abroad from $76 \%$ in 2015 to $64 \%$ in 2030 (ratio between the import / export balance of primary energy needed to cover the needs and gross domestic consumption), thanks to the strong growth of renewables and energy efficiency.

The Italian regulation around green energies has been hectic though effective. Results are there as the Law firm Norton Rose Fulbright puts it: Italy has one of the highest energy import dependence rates as compared to other EU member states. Lowering dependence on energy imports and complying with the European 20-20-20 green commitments (20 per cent cut in emissions, 20 per cent increase in energy efficiency per cent renewables generation by 2020) are two objectives at the heart of Italy's domestic energy policy.

The successive Italian Governments have implemented an Incentives regime since 2007. The Entity in charge is the the Gestore Servizi Energetici (GSE). The GSE is the state-owned company which promotes and supports renewable energy sources (RES) in Italy. In particular, GSE fosters sustainable development by providing support for renewable electricity (RES-E) generation and by taking actions to build awareness of environmentally-efficient energy uses. The sole shareholder of GSE is the Ministry of Economy and Finance, which exercises its rights in consultation with the Ministry of Economic Development (GSE, 2019).

The main activities of the GSE are the support for renewable electricity, the purchase of electricity from producers \& resale in the market and the support to institutions and to the Italian Public Administrations.

Support to renewable energy is usually performed by the implementation of several measures. Feed-in-tariffs or FiTs, Feed-in-premiums or FIPs, tenders, quota obligations and tradable green certificates orTGCs) or Contracts for Difference (CfDs) are usually applied as major support instruments. The Feed-in tariffs or FiT offers a long-term purchase agreement for the sale of renewable electricity. Usually, FiTs include three key points: a guarantee of dispatch, a long-term agreements and a payment levels based on the costs of technology (Serrano \& Lacal-Arántegui, 2016).

Italy introduced this support scheme in 2005. As explained it was the first Feed-in-tariffs or Conto Energia scheme. The most significant changes from previous requirements were the simplification of the administrative process with the abolition of the Preliminary investigation admission to tariffs phase before one would install the facility and subsequently requesting the incentive rate. In those first efforts the annual limit of incentive regime power (introduced by D.M. February 6, 2006) was replaced by a maximum aggregate incentive regime power of $1200 \mathrm{MW}$ over a period of grace of 14 months rising to 24 for public entities. Also there was a greater articulation of tariffs, with the intent to promote small architecturally integrated applications. Other measures taken were:

1. The introduction of a premium for photovoltaic plants with a combined use efficient energy.

2. The elimination of the $1,000 \mathrm{~kW}$ limits.

3. The Italian national cumulative target for capacity to be installed was raised to 3000 MW by 2016 .

This renewable incentives regime ranked among the highest global subsidies for RES. There have been two regimes in Italy. One for PV plants since 2007 and another for all energy plants fuelled by other types of RES since 2002. Once they qualify to participate in an incentive regime based on green certificates (GCs), which are issued by the GSE, traded between operators on a dedicated market, and surrendered to GSE at a fixed price. Pursuant to a law passed last year (Decree 6 July 2012) from 2016 the GC regime will be replaced by a dedicated FiT, which will be calculated on the basis of the average price for the sale of electricity during the relevant year.

As mentioned a feed-in tariff or FiT had been offered to solar PV plants by the Gestore Servizi Energetici (GSE). The FiT is paid based on the amount of energy produced and delivered into the grid and it was granted for a 20 year period. 
There have been five Conto Energia / FiT schemes: First FiT on $28^{\text {th }}$ July 2005 and $6^{\text {th }}$ February 2006. The $^{\text {. }}$ second FiT on $19^{\text {th }}$ February 2007. The third FiT on $6^{\text {th }}$ August 2010. The fourth one on $5^{\text {th }}$ May 2011 and the fifth FiT on $5^{\text {th }}$ July 2012. This Final scheme ended on the $6^{\text {th }}$ July 2013. It was said that this final Conto Energia $V$ would end once the total annual costs of cumulative reached $€ 6.7$ billion. And the GSE announced that "the Fifth Energy Bill ceased to apply July 6, 2013, that is after 30 calendar days after reaching an indicative cumulative cost of incentives of $€ 6.7$ billion per year, communicated by the AEEGSI's Decision (250/2013 /R /EFR)".

The situation created some dispute on the Italian Courts as the GSE suspended the application of the Regole per il mantenimento degli incentivi in Conto Energia on $9^{\text {th }}$ July 2015. Those norms or Regole provided a set of guidelines for the implementation and for any modifications to PV plants receiving incentives under any of the five FiT. This decision was subject to further discussions with the main industry association: the dialogue continues between the GSE and the main associations of operators on the Technical Document Reference (DTR) which regulates the maintenance of incentives in the Energy Bill. Waiting for the conclusion of the DTR and considering the fact that the matter might find specific regulation under the new decree, the GSE deems as appropriate to suspend the effectiveness of the DTR.

That meant a unilateral cancellation of any incentive from the GSE and new guidelines are still to be released. The question was raised to the Italian Constituational Court on $23^{\text {rd }}$ June 2015 by the Regional Administrative Tribunal in Rome (TAR Lazio) referred the question of the constitutional legitimacy of the spalma incentivi to the Italian Constitutional Court. The situation is explained by Narducci R., Steinhauer C. from McDermott Will \& Emery:

As we reported in our OTS from 12 August 2014, the spalma- incentivi required owners of photovoltaic (PV) plants with a nominal power exceeding $200 \mathrm{~kW}$ to choose one of the following changes to the originally awarded FiT:

1. A reduction of between 6 to8 per cent on the originally applicable feed-in tariff (FiT) rates. 2. A tariff reduction of between 17 per cent and 25 per cent against an extension of the payment period by four years. 3. An even higher reduction in a first period, followed by a corresponding increase in subsequent years.

The referral to the Constitutional Court had the effect of suspending all similar appeals currently pending before the TAR or before the Head of the State until the Constitutional Court makes its ruling. The Constitutional Court has scheduled a first hearing for 6 December 2016. Nevertheless, in January 2016, the GSE started to upload on its web portal an "addendum" to each FiT agreement in order to adjust the existing contracts to the disputed "spalma incentive" provisions. Many plant owners decided to challenge these amendments in court by filing new appeals or amending the previous ones. Others sent a formal statement of objection, while others remained passive, trusting that the GSE will not insist on the contract amendments should the Constitutional Court annul the "spalma incentive" provisions. In the meantime, indemnity claims have been filed against the Italian Government in respect to the "spalma incentive" provisions, based on the alleged violation of the Energy Charter Treaty. Four claims are pending before the International Centre for Settlement of Investment Disputes and one before the Arbitration Institute of the Stockholm Chamber of Commerce-SCC (Narducci \& Steinhauer, 2016).

Having said that one could see that the released numbers show a success of the FiT program: More than 17 GW of solar energy capacity were installed as a result, spread out across more than 526,000 different projects. Over half a million PV plants, with an aggregate production capacity of 17 GW. They are getting FiTs of a value of $€ 6.6$ billion per year and in 2015 solar photovoltaic (PV) systems in Italy generated 24,676 GWh of electricity, representing 9.1 per cent of Italy's domestic electricity production and 7.8 per cent of the country's overall consumption (Narducci \& Steinhauer, 2016). Also it is to be noted that the timing of the end of the FiT program for the Italy. Around the same date Spain and Portugal ended their programs and Germany is also reconsidering it (Ayre, 2013).

Moreover economic subsiding to the installation and grid connection of renewable energy plants in Italy was regulated, with exception of PV, since 2012, by MISE (Italian Economic Development Ministry) Decree 06/07/2012. This regulation established:

1. The feed-in-tariff and the feed-in-premium schemes.

2. The amount of the tariff in function of the energy sources and the nominal power of the plant.

3. The access mechanism to the subsiding. On $23^{\text {rd }}$ of June 2016 a new MISE decree was published. It decreased the tariffs level for each source of energy and power size of the plant.

The MISE decree 23/06/2016 established the rules for the incentive of renewable energy production from all sources, except PV, connected to the grid after its publication date. From 2016, the GC market will cease to operate and will be replaced by a FiT scheme. As explained all existing plants that were authorised by $11^{\text {th }}$ July 
2012 and came into operation before $30^{\text {th }}$ April 2013 (30 $0^{\text {th }}$ May in case of waste treatment plants) will switch to a FiT support regime.

By law, a proportion of the total amount of energy produced or fed into the grid by any one producer in Italy must be produced from a RES. Renewable incentives provided under the Italian legislative regime rank among the highest global subsidies for RES. Furthermore, premium incentives are available for certain types of plants.

The Italian Government has passed legislation, in the form of a series of decrees, to encourage the RES. Key points in terms of the incentive regime include:

1. State issued feed-in-tariff.

2. Contracts with the state owned energy company, Gestore Servizi Energetici (GSE) to sell energy to them (GSE, 2019).

3. Guaranteed off take agreements.

4. Up to twenty year duration.

The new decree that was issued on the $23^{\text {rd }}$ June 2016 introduced a lower tariff. The tariff established under the previous decree, dated $5^{\text {th }}$ July 2012 is kept valid for some categories of renewable energy plants. Renewable energy plants that require direct access to the feed in tariff as per the new decree, connected to the grid before $30^{\text {th }}$ June 2017.

In this case, the request of the direct access had to be submitted before $31^{\text {st }}$ December 2017 or before the date at which the mean cost of the incentives, calculated by GSE exceeds $€ 5.8$ billion. For plants which are connected to the grid before the $30^{\text {th }}$ June 2017 , the incentive is 0.268 euro $/ \mathrm{kWh}$. For plants connected during the period 1 July 2017 to 31 December 2017, the incentive drops to $0.19 € / \mathrm{kWh}$. In addition to fiscal measures, the Government has taken other steps to support the renewable energy sector, for example by making it easier for developers (VV.AA., 2018).

It is important to remember that under the aforementioned MISE decree 23/06/2016 the following categories of renewable energy plants can require direct access to the feed in tariff with the new decree and can obtain the "old" tariff level if connected to the grid before $30^{\text {th }}$ June 2017:

1. Wind Energy plants with a power up to $60 \mathrm{~kW}$.

2. Oceanic hydraulics energy plants with a power up to $60 \mathrm{~kW}$.

3. Hydraulics energy plants with a power up to $250 \mathrm{~kW}$ using existing water channels.

4. Biomass (type A or type B) energy plants with a power up to $200 \mathrm{~kW}$.

5. Biogas energy plants with a power up to $100 \mathrm{~kW}$

Therefore the Micro Wind Energy plants are the only reliable category that can take advance of the opportunity provided by the new MISE decree having the following features:

1. Easy permitting procedure (PAS);

2. Short construction time;

3. Short grid connection time (usually);

4. Good public acceptability;

5. Good production (with a correct scouting of the wind resource); Meteorological reanalysis for ten or more years or historical data correlation are useful instruments for the wind resource assessment. Wind Energy Atlas could be used for a first guess scouting only due to its low spatial resolution.

If one focuses on the case of the Wind energy in Italy one would see a contradictory panorama. In the ranking of the European countries with the highest wind production Italy has ranked fifth in 2017 with, behind Germany, Spain, France and the United Kingdom (Bergamasco, 2018). The Associazione Nazionale Energia del Vento-ANEV, the Italian national Association of Wind Energy, draws the attention of the Institutions and of the relevant Ministries on the urgency of issuing the Renewable Decree for the period 2018-2020 (ANEV, 2019), so that these goals can be maintained and overcome. "Wind energy proves to be a clean renewable source, environmentally friendly, able to improve the trade balance of countries and create jobs" said the Association (Bergamasco, 2018). The current number of power from wind power is of 9,250 MW. The target for 2030 as the ANEV reminds is of 17,150 MW of which $400 \mathrm{MW}$ would come from mini wind mills and $950 \mathrm{MW}$ from off shore sources. However the latest data releases show a decreased in the number of wind power capacity installed in 2017: +283 MW in 2016 vs.-+252 MW in 2017 (Fraile \& Mbistrova, 2018). 
This brings a shadow of controversy on the incentives scheme promoted by the Italian authorities. The access to the incentive schemes, in the light of the MISE decree 23/06/2016, ended after 30 days starting from the first of the following dates:

1. the date at which the annual mean cost of the incentive, calculated by GSE (Gestore Servizi EnergeticiEnergy Services Management department) will raise up to 5,8 billions of Euro.

2. $1^{\text {st }}$ December 2017 for the plants that access directly to the feed in tariff (for example Wind Energy Plants with a power not higher than $60 \mathrm{~kW}$ ). This limit seems to favour the implantation of mini wind farm with lower power.

As reported by the GSE in the Scenario Analysis (June 2016) the raising of the annual mean cost, up to 5,8 billion Euro, could not be reached in 2016 and would be avoided in 2017 (except for the worst case scenario with the lowest energy market price - PUN). $31^{\text {st }}$ December 2017 was the limit date for the direct access to the incentive scheme.

The tariff level established by the old decree was kept valid for some categories of renewable energy plants, inter alia: Renewable energy plants that require direct access to the feed in tariff as per the new decree, connected to the grid before $30^{\text {th }}$ June 2017. In this case, the request of the direct access can be submitted before $31^{\text {st }}$ December 2017 or before the date at which the annual mean cost of the incentives, calculated by GSE (Gestore Servizi Energetici - Energy Services Management department) will raise up to 5,8 billions of Euro. The duration of the incentive is equal to the operational life of the plant: 20 years.

In 2017 the figures do not show a direct relationship between this incentives scheme and a change in the trends regarding wind energy implementation. This trend is common to fellow Southern Europe countries. While in the period 2004-2011 Southern Europe countries (Spain, Portugal, Italy and Greece) showed a remarkable concentration in the growth of wind power installation, since 2012 the trend have been diminishing.

Figure 5. Geographical concentration of the annual wind power installations

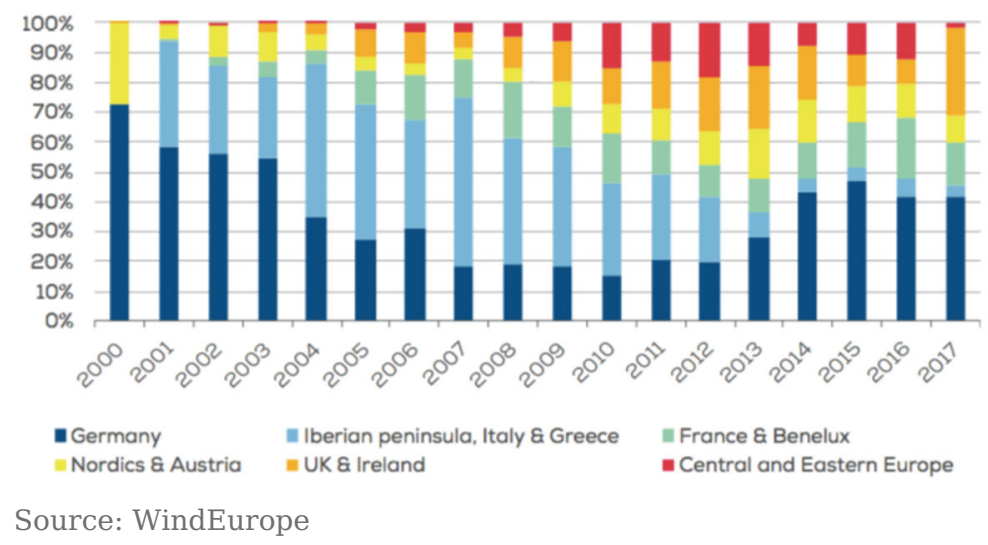

Also, in 2017 the Italian case showed a percentage of the average annual electricity demand covered by wind of $5.2 \%$. This figure is much lower than the EU-28 average of $11.6 \%$. Countries such a Denmark shows a $44.4 \%$ and even fellow Southern European countries display much healthier figures: Spain $18.6 \%$ or Portugal $24.2 \%$ (Fraile \& Mbistrova, 2018).

The Italian case also seems to show an absence of offshore wind farms. The Mediterranean Sea seems less attractive to public and private wind farm-related investment. The Italian government only recently awarded the country's first offshore wind farm license, with a small 30-megawatt development scheduled to take place over the coming years near Taranto in south-eastern Italy. ANEV is working towards the installation of other developments over the next several years but no specific news have been released yet.

Also within the country there are severe regional differences. The installation and use of renewable energy plants vary considerably in Italy on the basis of numerous conditions. For example, big hydroelectric plants have been developed in specific locations and the same would apply for the construction of wind farms where there have been a particular emphasis on windiness, the orography and the accessibility of sites etc. The use of biogas plants is increased where there is greater availability of the energy source, etc. It is noticeable that $76 \%$ of the electricity produced from water sources is concentrated in only 6 regions in Northern Italy. On the contrary, $90 \%$ of the electricity produced from wind power is concentrated in 6 regions of Southern Italy. The geothermal plants are developed exclusively in the Tuscany Region, where there are certain characteristics of endogenous heat that can be used for the electricity production (VV.AA., 2018). 
Figure 6. Italian regional share of production on the national total
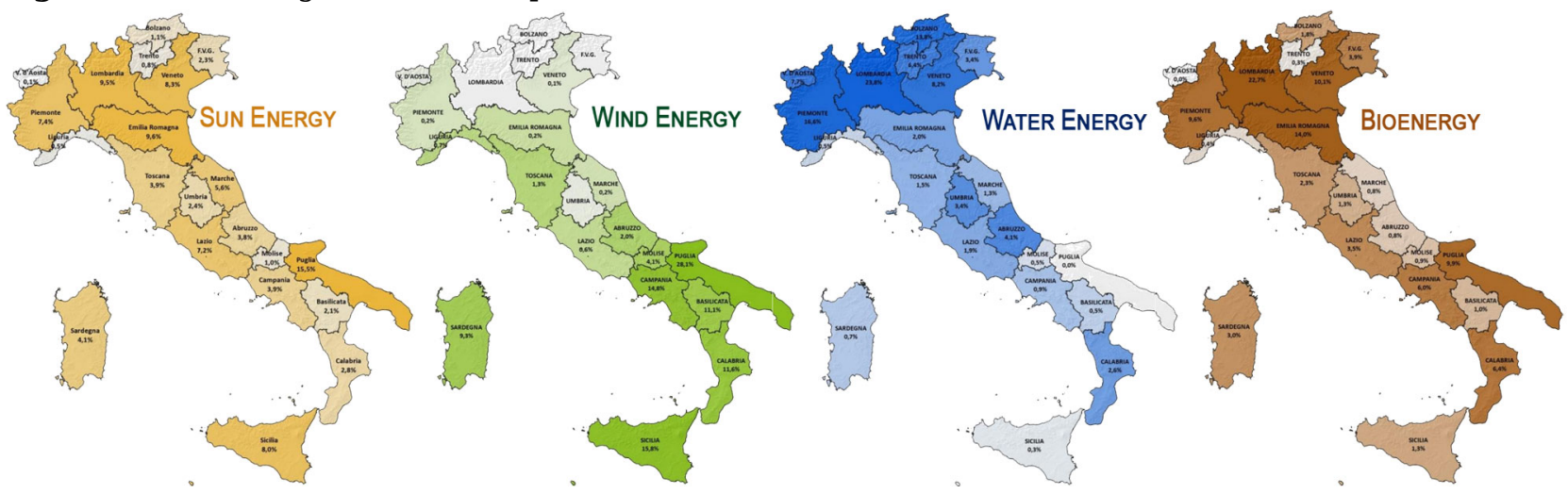

Source: VV.AA. (2018)

The mentioned distribution is the situation as it is. But the regional goals ambitions do not go together with those figures. Some of the Northern Italy regions that show low levels of penetration in some renewable energies like wind energy have much more ambitious plans for the year 2020. The following table explains the difference in goals.

Table 2. Renewable energy growth goals in the Italian regions (in \%)

\begin{tabular}{|c|c|c|c|c|c|c|}
\hline \multirow[b]{2}{*}{ Regions or Autonomous Provinces } & \multicolumn{6}{|c|}{ Regional goal for the year (\%) } \\
\hline & $\begin{array}{l}\text { Year of } \\
\text { reference } \\
(2005)\end{array}$ & 2012 & 2014 & 2016 & 2018 & 2020 \\
\hline Abruzzo & 5.8 & 10.1 & 11.7 & 13.6 & 15.9 & 19.1 \\
\hline Basilicata & 7.9 & 16.1 & 19.6 & 23.4 & 27.8 & 33.1 \\
\hline Calabria & 8.7 & 14.7 & 17.1 & 19.7 & 22.9 & 27.1 \\
\hline Campania & 4.2 & 8.2 & 9.8 & 11.6 & 13.8 & 16.7 \\
\hline Emilia Romagna & 2.0 & 4.2 & 5.1 & 6.0 & 7.3 & 8.9 \\
\hline Friuli V. Giulia & 5.2 & 7.6 & 8.5 & 9.6 & 10.9 & 12.7 \\
\hline Lazio & 4.0 & 6.5 & 7.4 & 8.5 & 9.9 & 11.9 \\
\hline Liguria & 3.4 & 6.5 & 8.0 & 9.5 & 11.4 & 14.1 \\
\hline Lombardia & 4.9 & 7.0 & 7.7 & 8.5 & 9.7 & 11.3 \\
\hline Marche & 2.6 & 6.7 & 8.3 & 10.1 & 12.4 & 15.4 \\
\hline Molise & 10.8 & 18.7 & 21.9 & 25.5 & 29.7 & 35.0 \\
\hline Piemonte & 9.2 & 11.1 & 11.5 & 12.2 & 13.4 & 15.1 \\
\hline Puglia & 3.0 & 6.7 & 8.3 & 10.0 & 11.9 & 14.2 \\
\hline Sardegna & 3.8 & 8.4 & 10.4 & 12.5 & 14.9 & 17.8 \\
\hline Sicilia & 2.7 & 7.0 & 8.8 & 10.8 & 13.1 & 15.9 \\
\hline TAA - Bolzano & 32.4 & 33.8 & 33.9 & 34.3 & 35.0 & 36.5 \\
\hline TAA - Trento & 28.6 & 30.9 & 31.4 & 32.1 & 33.4 & 35.5 \\
\hline Toscana & 6.2 & 9.6 & 10.9 & 12.3 & 14.1 & 16.5 \\
\hline Umbria & 6.2 & 8.7 & 9.5 & 10.6 & 11.9 & 13.7 \\
\hline Valle D'Aosta & 51.6 & 51.8 & 51.0 & 50.7 & 51.0 & 52.1 \\
\hline Veneto & 3.4 & 5.6 & 6.5 & 7.4 & 8.7 & 10.3 \\
\hline ITALY & 5.3 & 8.2 & 9.3 & 10.6 & 12.2 & 14.3 \\
\hline
\end{tabular}

Source: (VV.AA., 2018)

The special autonomy of Trentino and of neighbouring Alto Adige-Südtirol, which together with Trentino comprises the Autonomous Region of Trentino Alto Adige, was born from an agreement between Italy and Austria, signed in Paris on 5 September 1946. The basic rule of the Autonomous Provinces lies on a Statute. A First Statue went on to be approved by the Italian Constituent Assembly (in charge of drafting the Constitution of the post-fascist Republic of Italy) and subsequently became Constitutional through Law No. 5, passed on 26 February 1948 (VV.AA., 2007). A Second Statute was adopted in 1972 and it is the current basic norm ${ }^{54}$. There is an incoming referendum at the end of 2018 that will ask about an in-depth reform of the Statute (VV.AA., 2018).

Within the competence of the Statue, the region has developed a local environmental policy around the energy production issues. The autonomous region issues a Legislative Decree in 1999 entitling the region with autonomous power on the implementation rules of the Special Statute of the Trentino Alto Adige Region on the subject of water resources, hydraulic works and concessions of large derivations for hydroelectric purposes, production and distribution of energy. The article 9 of such Legislative Decree states "(it) provides for the transfer to the Autonomous Provinces of Trento and Bolzano, for the respective territory, of the functions in the field of energy exercised both directly by the central and peripheral bodies of the State is through national 
public bodies or multi provincial institutions, except as provided for in paragraph 3". The Italian State remains in charge of: a) the definition of the objectives of national energy policy, of the relative ones national programs and acts of direction and coordination; b) (Omitted) c) construction and exercises or of electricity production plants from conventional sources of more than $300 \mathrm{MW}$ of thermal power, as well as networks for the transport of electricity constituting the national transmission grid, the issue of the related technical standards and the national level networks of gas pipelines with working pressure above 40 bar and pipelines (prior mandatory opinion of the Province concerned); d) the regulation concerning the exportation, the importation of energy; e) the determination of the general technical-constructive criteria and the issue of the essential technical standards of production plants, conservation, energy storage and distribution; f)the determination of the technical and commodity characteristics of energy produced and distributed; g) (Omitted).

On a practical level, the Autonomous Provinces have created a Provincial Plan for the Energy and the Environmental for the period 2013-2020: "Piano energetico-ambientale provinciale (P.E.A.P.) 2013-2020" (VV.AA., 2018). In such a Plan it is mentioned the particular advantageous situation for the Trentino Alto Adige Region as the wind resource in mountain environments such as the Trentino Alto Adige has particular characteristics such as low temperatures, high speed for the win and high air turbulence. They carry severe loading conditions but also significant energy potentials that can be lend to attractive management prospects. Additionally the resources of the territory are mainly located in uninhabited areas. Moreover, for some years they have been on the market wind turbines specifically designed to work regularly even in the presence of particular weather conditions such as the ones at Trentino Alto Adige Region. However it also warns that the national incentive program may apply some limited applications for small systems in areas with an above average wind speed. Also, the PEAP reminds of the fact that much suitable land for wind mills is under environmental protection thus the mini wind farms have been the best way to have a lower impact in the surrounding and getting local construction permissions .

These Plans are part of a much ambitious strategy, as the Region has proposed to reach energy self-sufficiency by 2050, focusing on the contribution of renewable sources and aims to achieve the objective "Trentino Zero Emission" with the tendency reduction in emissions of carbon dioxide and other climate-change gases by 50 percent compared to 1990 levels by the year 2030 and 90 percent by the year 2050. It is also of relevance to learn that since as early as 2007 the local research centres have been studying the behaviour of various wind turbines and in particular of mini- turbines, suitable for realities such as the Trentino one, which do not have strong and constant winds like those of the Atlantic, but which can equally profitably exploit the force of the local winds to produce renewable energy with small plants. The University of Trento led the project in finding optimal turbines (VV.AA., 2007). It is remarkable that the local experts point that from a technical-economic point of view, the mini- wind farms can be less advantageous than the single turbine. There is a mistake in thinking that mini-turbines are miniaturizations of the medium and wind turbines large size, with which they can only share a few design aspects. They require one specific design, oriented to simplicity of construction, reliability and reduced maintenance, in addition to the use of low-cost construction technologies and components that are easy to find. There is an open debate on the technical-economic opportunity to design mini-turbines of smaller size (1-60 kW) using technologies already used in larger machines. Solutions such as active control of power and over-power, active control of yaw, the use of dedicated stake profiles, etc., involves financial investments, technological acquisitions, research activities and experimentation periods with substantial economic impacts for the size of companies in this segment and for current sales volumes (Battisti, 2015).

The local constraints have made that a number of local start-ups are developing projects that are place the Trentino Region in vanguard of the research in mini wind-farm and mini-turbines. These projects are winning several European international contests (VV.AA., 2017).

\section{Regulation impact}

As a result of this public subsidies and incentives regulation many plants were built, but did not any more get incentives, or plants had to be built very quickly in order to get the incentives, but, in order to be built quickly, signed financings with banks which were very badly negotiated. The matter let to a sector crisis that the country is still recovering from.

The PV plants built in Italy between 2010 and 2011/ beginning 2012, received very interesting incentives. However many of those plants are poorly financed and the ownership is looking to sell them out. The returns from those plants are not double digit, but they mean a stable and constant cash flow in and having reached the €6.6. B. limit it is easy for the owner to calculate a steady amount of money cashing in their accounts.

Furthermore mini wind farms in Italy are display interesting characteristics: as said above, from 2012 there were extremely very low, or practically not existing incentives for green energy plants in Italy, since the boom between 2007 and 2012 needed to be slowed down. But, there was segments, a niche, were still high incentives were given: wind turbines up to $200 \mathrm{kWp}$ nominal power, the so called "mini wind turbines". 
Additionally since the European Governments intents to unify the incentives laws throughout Europe from 2018 onwards, the Italian Government just kept the actual situation. Therefore, at the moment, mini wind farms in Italy are paid an interesting incentive. There will not be the situation as in 2011/2012, that after a boom the Government will cut drastically the incentives, since given the small maximal dimension of each single plant ( $\max 200 \mathrm{kWp}$ ), even if many turbines will be built, the total dimension is not influencing drastically the total size of all power plants in Italy, so, there is no drastic cut to be expected. On the other hand, enforcing this situation is the fact, that the Italian Government just confirmed for another year the incentives for mini wind farms. This means mini wind projects can be built for another year, at least until July 2017 and they are being granted by the Italian Government with interesting incentives for 20 years.

At the moment we profit form the eased Legal conditions for the realization of Micro Wind Farms in Italy, which are heavily supported by the Italian Government, which want small wind turbines to be built, since their visual and environmental impact is much lower.

\section{Conclusions}

The key ideas are: RES policies are becoming more and more relevant. Wind power is growing more and more. Southern European countries used to show a relevant growth in RES but since 2012 it has notably declined. Italy is showing an even lower growth even compared with fellow Southern Europe countries. However Italy is meeting its targets. Italy is implementing FiT policies with controversial results. Italy is encouraging the implementation of smaller wind farms $(<60 \mathrm{MW})$ that are also faster to be built. Off-shore wind production remains small and is not taking off.

Trentino Alto Adige is particular Region when it comes to the global Italian efforts. It shows a low penetration of RES but very ambitious plans. As far as wind energy is concerned there are two constraining factors: Particular kind of winds and strong local environmental and landscape protection. Trentino Alto Adige has its own Policies and Plan within the National efforts. Trentino Alto Adige is also leading the R+D regarding the particular niche of mini wind turbines. It hopes it will help to catch up with the rest of more advanced regions in Italy and in the EU. Right now, everything is under discussion for the new EU budgets (2020-26).

\section{Acknowledgements}

Paper supported by the research group “Grupo de Investigación para el Estudio y seguimiento del ciclo económico de la Universidad Rey Juan Carlos (GESCE-URJC)".

\section{FootNotes}

${ }^{1}$ The national targets as set out in the National Reform Programmes (NRP) in April 2015. The national emissions reduction targets defined in Decision 2009/406/EC (or "Effort Sharing Decision") concern the emissions not covered by the Emissions Trading System. The emissions covered by the Emissions Trading System will be reduced by $21 \%$ compared to 2005 levels. The corresponding overall emission reduction will be $-20 \%$ compared to 1990 levels. Targets are defined in terms of reduction of emissions or maximum increase in emissions.

${ }^{2}$ Brussels, 3.3.2010 COM (2010) 2020 final Communication from the Commission.

${ }^{3}$ Decreto interministeriale 10 novembre 2017 - Strategia energetica nazionale. 


\section{References}

ANEV (2019). Video Istituzionale ANEV. Retrieved from http://www.anev.org/multimedia/

Ayre, J. (2013). Italian Solar Energy Feed-In Tariff Payments Ceasing On July 6 -. Retrieved from http://solarlove.org/italian-solar-energy-feed-in-tariff-payments-ceasing-on-july-6/

Battisti, L. (2015). Gli ambiti di sviluppo del minieolico in Italia. University of Trento. Retrieved from https://www.qualenergia.it/sites/default/files/articolo-doc/speciale-ambiti-sviluppo-minieolico-initalia_qualenergia-battisti.pdf

Bergamasco, C. (2018). A gennaio nuovo record per l'eolico europeo che copre il 22,7 per cento della domanda di energia. Lifeate. Retrieved from https://www.lifegate.it/persone/stile-di-vita/nuovo-recordeolico-europeo

European Commission (2005). Kyoto Protocol. Retrieved from https://europa.eu/rapid/pressrelease_MEMO-05-49_en.htm?locale=en

European Commission (2009). 2020 climate \& energy package. Retrieved from https://ec.europa.eu/clima/policies/strategies/2020_en

European Commission (2010). Europe 2020 A strategy for smart, sustainable and inclusive growth. Retrieved from http://ec.europa.eu/europe2020/index_en.htm

European Commission (2010). Share of renewables in gross inland energy consumption. Retrieved from https://ec.europa.eu/eurostat/statistics-explained/index.php?title=Energy

European Commission (2015). Europe 2020 in a nutshell. Retrieved from http://ec.europa.eu/europe2020/europe-2020-in-a-nutshell/index_en.htm

Eurostat (2018). Share of energy from renewable sources 2004-2016. Retrieved from https://ec.europa.eu/eurostat/statisticsexplained/index.php?title=File:Figure_1-Share_of_energy_from_renewable_sources_2004-2016.png

Feldman, D., Barbose, G., Margolis, R., James, T., Weaver, S., Wiser, R., ... Wiser, R. (2014). Photovoltaic (PV) Pricing Trends: Historical, Recent, and Near-Term Projections. U.S. Department of Energy. Retrieved from http://www.nrel.gov/docs/fy14osti/62558.pdf

Fraile, D., \& Mbistrova, A. (2018). Wind in power 2017. Windeurope. Retrieved from https://windeurope.org/wp-content/uploads/files/about-wind/statistics/WindEurope-AnnualStatistics-2017.pdf

GSE (2019). What we do?. Gestore dei Servizi Energetici. Retrieved from https://www.gse.it/en/what-we-do

Jordan, P. G. (2013). Solar Energy Markets: An Analysis of the Global Solar Industry. Wrentham (MA), USA: Elsevier Inc.. https://doi.org/10.1016/C2011-0-07234-4

Klessmann, C., Held, A., Rathmann, M., \& Ragwitz, M. (2011). Status and perspectives of renewable energy policy and deployment in the European Union-What is needed to reach the 2020 targets?. Energy Policy, 39(12), 7637-7657. https://doi.org/10.1016/j.enpol.2011.08.038

Narducci, R., \& Steinhauer, C. (2016). Key Developments in The Photovoltaic Sector in Italy. McDermott Will \& Emery. Retrieved from https://www.mwe.com/insights/key-developments-in-the-photovoltaic-sector/

Serrano, J., \& Lacal-Arántegui, R. (2016). A review of regulatory framework for wind energy in European Union countries: Current state and expected developments. Renewable and Sustainable Energy Reviews, 56, 588-602. https://doi.org/10.1016/j.rser.2015.11.091

Sánchez-Bayón, A. (2014). Fundamentos de derecho comparado y global: ¿Cabe un orden común en la globalización?. Boletín Mexicano de Derecho Comparado, 47(141), 1021-1051. https://doi.org/10.1016/S0041-8633(14)71183-4

Sánchez-Bayón, A. (2014). Global System in a Changing Social Reality: How to Rethink and to Study It. Beijing Law Review, 05(03), 196-209. https://doi.org/10.4236/blr.2014.53019

Sánchez-Bayón, A. (2015). Política, Derecho y Administración en la Globalización: ¿es posible un orden común?. Pensamiento Americano, 8(15). Retrieved from http://publicaciones.americana.edu.co/index.php/pensamientoamericano/article/view/84

UNFCCC (2014). Kyoto Protocol to enter into force 16 February 2005. Retrieved from https://unfccc.int/files/press/news_room/press_releases_and_advisories/application/pdf/press041118_eng. pdf

United Nations (2005). The Kyoto Protocol - Status of Ratification. Retrieved from https://unfccc.int/process/the-kyoto-protocol/status-of-ratification

VV.AA. (2007). Campo eólico sperimentale di Trento. Provincia Autonom Di Trento

VV.AA. (2008). The EU's Target for Renewable Energy: 20\% by 2020. House of Lords. Retrieved from https://publications.parliament.uk/pa/ld200708/ldselect/ldeucom/175/175.pdf

VV.AA. (2011). Italian PV Market 2006-2011. Optics.org

VV.AA. (2013). I primi tre conti energia. Camera dei deputati, Italia. Retrieved from https://leg16.camera.it/temiap/temi16/conti_energia_123.pdf 
VV.AA. (2016). About SOER 2015. The European environment - state and outlook 2015: an integrated assessment of the European Environment. European Environment Agency. Retrieved from https://www.eea.europa.eu/soer-2015/about

VV.AA. (2017). Il minieolico roveretano vince in Europa. Trentino. Retrieved from http://www.giornaletrentino.it/cronaca/trento/il-minieolico-roveretano-vince-in-europa-1.396894

VV.AA. (2017). Renewables, Power and Energy use forecast to 2050. DNV GL - Energy. Retrieved from https://www.ourenergypolicy.org/wp-content/uploads/2017/09/DNV-GL_Energy-TransitionOutlook-2017_renewables_lowres-single_0109.pdf

VV.AA. (2017). Strategia Energetica Nazionale-SEN. Ministero dello Sviluppo Economico e del Ministero dell'Ambiente e della Tutela del Territorio e del Mare. Retrieved from https://www.mise.gov.it/images/stories/documenti/Testo-integrale-SEN-2017.pdf

VV.AA. (2018). Approvato All'unanimità Dalla Consulta Il Documento Conclusivo Con Proposte Per La Riforma Dello Statuto Di Autonomia. Riforma Dello Statuto. Retrieved from https://www.gse.it/documenti_site/Documenti GSE/Studi e scenari/Fonti Rinnovabili in Italia e in Europa verso gli obiettivi al 2020.pdf

VV.AA. (2018). Fonti rinnovabili in Italia e in Europa Verso gli obiettivi al 2020. GSE-Gestore Servizi Energetici. Retrieved from https://www.gse.it/documenti_site/Documenti GSE/Studi e scenari/Fonti Rinnovabili in Italia e in Europa verso gli obiettivi al 2020.pdf

VV.AA. (2018). La situazione energetica nazionale nel 2017. Ministero dello Sviluppo Economico. Retrieved from https://www.mise.gov.it/index.php/it/198-notizie-stampa/2039948-la-situazione-energetica-in-italiasi-consolida-il-ruolo-delle-energie-rinnovabili-e-diminuisce-la-dipendenza-estera 